\title{
Increased risk of respiratory symptoms in young smokers of low tar cigarettes
}

\author{
ARJA H RIMPELÅ, MATTI K RIMPELÅ
}

\begin{abstract}
The effect of cigarettes yielding less than $10 \mathrm{mg}$ tar was investigated in a representative sample $(n=4729)$ of 16 and 18 year old Finns. The rate of response was $80 \%$. Cough and phlegm were significantly increased in young people smoking low tar cigarettes. When more than nine cigarettes were smoked daily respiratory symptoms were 2.4-6.2 times more prevalent among those who smoked low tar cigarettes than among those who never smoked. No differences were found between the smokers of low tar and medium tar cigarettes (yielding tar 10-18 mg). These data disagree with the hypothesis that the new low tar brands of cigarettes are less likely to cause respiratory symptoms than the old medium tar brands.
\end{abstract}

\section{Introduction}

Finland's smoking and health policy has aimed at reducing the tar, nicotine, and carbon monoxide yields of cigarettes in order to decrease the health hazards of smoking. This policy was founded on results of studies that showed plain cigarettes to be more hazardous to health than filter cigarettes and higher tar cigarettes more hazardous than lower tar cigarettes. ${ }^{1-5}$ In most studies the yields of tar and nicotine from cigarettes have been high compared with the new brands containing 1-10 mg tar in each cigarette and low amounts of nicotine. A few studies

Finnish Cancer Registry, SF 00170 Helsinki 17, Finland

ARJA H RIMPELÄ, MD, research fellow

Department of Public Health Science, University of Helskinki, SF 00290 Helsinki 29, Finland

MATTI K RIMPELÄ, MD, associate professor in medical sociology

Correspondence to: Dr Matti Rimpelä, Department of Community Health, London School of Hygiene and Tropical Medicine, London WC1E 7HT. on adult populations evaluating the effects on health of these new brands have suggested that the risk of several diseases related to smoking is not reduced among smokers of low tar cigarettes. $^{6-9}$ Only one study showed a lower risk of chronic cough and phlegm in women who smoked low tar cigarettes $(<10 \mathrm{mg})$. $^{6}$

The marketing of low tar cigarettes started only a few years ago. Nearly all adults who smoke low tar cigarettes previously smoked higher tar cigarettes before switching to low tar brands. People who have only ever smoked low tar cigarettes can be found only among young people who started smoking after these new brands came on the market. In this study respiratory symptoms of young people were used as an indicator of the harmfulness of smoking low tar cigarettes. Our purpose was to find out the effects on health of cigarettes yielding less than $10 \mathrm{mg}$ tar.

\section{Subjects and methods}

In February 1983 a questionnaire was sent to a nationally representative sample of 16 and 18 year old Finns. The sample consisted of all persons born during 20-31 July inclusive in 1964 and 1966 $(\mathrm{n}=4729)$. The response rate was $80^{\circ}{ }_{0}\left(87^{\circ}{ }_{0}\right.$ among girls and $73^{\circ}{ }_{0}$ among boys). Two further attempts were made to obtain completed questionnaires from the non-responders. Distributions of sex, place of residence, and province of the respondents reflected those among the normal population according to national statistics.

Questions were asked about the occurrence of respiratory symptoms (a cough and phlegm in the morning, or a cough and phlegm during the day or at night during the last few days preceding the study). Detailed questions about smoking habits were asked. The definition of a daily smoker and the exact form of the questions have been reported previously with a discussion of the validity and repeatability of the method. ${ }^{10}$ The tar, nicotine, and carbon monoxide yields of every brand of cigarette sold in Finland are estimated twice a year by the State Technical Research Centre using standard methods (A Leppänen, $H$ Liukkonen-Lilja. Analysis of tobacco smoke. Summary of studies during 1977-80. State Technical Research Centre of Finland. Research report 86. Espoo 1982).

The following categories of smokers were defined: (1) never smoked: had smoked at most 50 cigarettes, cigars, or pipefuls of tobacco during their lifetime $(n=2034)$; (2) low tar cigarette smokers : 
daily smokers who reported smoking only brands of cigarettes yielding less than $10 \mathrm{mg} \operatorname{tar}(\mathrm{n}=373)$; (3) medium tar cigarette smokers: daily smokers who reported smoking only cigarette brands yielding $10-18 \mathrm{mg} \operatorname{tar}(n=435)$; (4) all others $(n=926)$. The fourth category included those daily smokers who smoked various types of tobacco or mixed medium and low tar brands, occasional smokers, and former smokers. This group was not used in the analysis. The second and third categories were divided further into two groups according to the daily consumption of cigarettes (table I).

Significances $(p<0.05)$ were estimated by the Mantel-Haenszel procedure, ${ }^{11}$ and confidence limits for proportions were calculated. ${ }^{12}$

TABLE I-Mean number of cigarettes smoked daily by smokers of low tar $(<10 \mathrm{mg})$ and medium tar $(10-18 \mathrm{mg})$ cigarettes

\begin{tabular}{|c|c|c|c|c|c|c|}
\hline & \multicolumn{2}{|c|}{ Total } & \multicolumn{2}{|c|}{ 1-9 cigarettes } & \multicolumn{2}{|c|}{$10+$ cigarettes } \\
\hline & Low tar & Medium tar & Low tar & Medium tar & Low tar & Medium tar \\
\hline Boys & $\begin{array}{c}11 \cdot 0 \\
(\mathrm{n}=115)\end{array}$ & $\begin{array}{c}12 \cdot 4 \\
(n=268)\end{array}$ & $\begin{array}{c}5 \cdot 8 \\
(n=43)\end{array}$ & $\begin{array}{c}4.9 \\
(n=79)\end{array}$ & $\begin{array}{c}14 \cdot 1 \\
(n=72)\end{array}$ & $\begin{array}{c}15 \cdot 5 \\
(n=189)\end{array}$ \\
\hline Girls & $\begin{array}{c}8.5 \\
(\mathrm{n}=258)\end{array}$ & $\begin{array}{c}9 \cdot 7 \\
(\mathbf{n}=167)\end{array}$ & $\begin{array}{c}4.5 \\
(n=143)\end{array}$ & $\begin{array}{c}4 \cdot 8 \\
(n=81)\end{array}$ & $\begin{array}{c}13.5 \\
(n=115)\end{array}$ & $\begin{array}{c}14 \cdot 4 \\
(n=86)\end{array}$ \\
\hline
\end{tabular}

\section{Results}

All symptoms were significantly more common among the smokers of low tar cigarettes than among those who had never smoked, while the differences between the low tar and medium tar groups were small (table II). The difference in the prevalence of phlegm in the morning between the low tar and medium tar groups was, however, significant. The results were similar for both sexes.

When the number of cigarettes smoked daily was 10 or more

TABLE II-Prevalences ( $\%$ ) adjusted for sex of respiratory symptoms during last few days preceding study and $95^{\circ}$ confidence intervals $(C I)$ by type of cigarette smoked

\begin{tabular}{|c|c|c|c|}
\hline Symptom & $\begin{array}{l}\text { Never } \\
\text { smoked }\end{array}$ & $\begin{array}{c}\text { Low tar } \\
\text { cigarettes }\end{array}$ & $\begin{array}{l}\text { Medium tar } \\
\text { cigarettes }\end{array}$ \\
\hline $\begin{array}{l}\text { Morning phlegm: } \\
\text { Prevalence } \\
95 \% \text { CI } \\
\text { n }\end{array}$ & $\begin{array}{c}2 \cdot 7 \\
2 \cdot 0-3 \cdot 5 \\
2031\end{array}$ & $\begin{array}{c}7 \cdot 6 \\
6 \cdot 1-9 \cdot 1\end{array}$ & $\begin{array}{l}11 \cdot 4 \\
9 \cdot 8-13 \cdot 0 \\
435\end{array}$ \\
\hline $\begin{array}{l}\text { Morning cough: } \\
\text { Prevalence } \\
95^{\circ} \text {. CI } \\
\text { n }\end{array}$ & $\begin{array}{c}6 \cdot 3 \\
5 \cdot 2-7 \cdot 3 \\
2031\end{array}$ & $\begin{array}{l}20 \cdot 7 \\
18 \cdot 5-22 \cdot 9 \\
373\end{array}$ & $\begin{array}{l}20 \cdot 5 \\
18 \cdot 5-22 \cdot 5 \\
435\end{array}$ \\
\hline $\begin{array}{l}\text { Phlegm day or night: } \\
\text { Prevalence } \\
95{ }^{\prime} \text {. CI } \\
\text { n }\end{array}$ & $\begin{array}{c}5 \cdot 2 \\
4 \cdot 3-6 \cdot 2 \\
2001\end{array}$ & $\begin{array}{l}13 \cdot 8 \\
11 \cdot 9-15 \cdot 7 \\
370\end{array}$ & $\begin{array}{l}13 \cdot 2 \\
11 \cdot 5-14 \cdot 9 \\
432\end{array}$ \\
\hline $\begin{array}{l}\text { Cough day or night: } \\
\text { Prevalence } \\
95^{\circ}{ }_{0} \text { CI } \\
\text { n }\end{array}$ & $\begin{array}{l}19 \cdot 1 \\
17 \cdot 3-20 \cdot 8 \\
2001\end{array}$ & $\begin{array}{l}43 \cdot 9 \\
41 \cdot 2-46 \cdot 6 \\
370\end{array}$ & $\begin{array}{l}40 \cdot 6 \\
38 \cdot 2-43 \cdot 1 \\
432\end{array}$ \\
\hline
\end{tabular}

respiratory symptoms were $2 \cdot 4-6 \cdot 2$ times more common among the smokers of low tar cigarettes than among those who had never sinoked, and the differences were significant (table III). Only minor differences in respiratory symptoms were seen between smokers of low tar and medium tar cigarettes; none of these differences was significant. In the group smoking one to nine cigarettes a day the differences between the smokers of low tar and medium tar cigarettes were small and not significant. When the smokers of low tar cigarettes in this group were compared with the non-smokers the prevalence of symptoms of cough and phlegm during the day or night differed significantly from those of non-smokers only among girls (table III). Stratification by age, level of education, and father's occupation did not alter the results.

\section{Discussion}

Groups of smokers were well defined in the analyses to make the contrasts as clear as possible. The smokers of low tar cigarettes reported smoking only brands of cigarette yielding less than $10 \mathrm{mg}$ tar a cigarette and no other types of tobacco. Similarly the smokers of medium tar cigarettes reported smoking only medium tar brands (10-18 $\mathrm{mg}$ tar). The group that never smoked had only tried smoking, if at all. Although the history of smoking among our subjects was short, it is possible that some of the smokers of low tar cigarettes had previously smoked medium tar cigarettes. Furthermore, the possibility that the smokers of low tar cigarettes had selected these brands because they already had respiratory symptoms cannot be excluded. The effect of these possible biases on the overall result of this study was supposed to be small. A follow up study, which is now in progress, will give more information.

An earlier Finnish study showed that, in addition to smoking, sex and level of education had a small independent effect on respiratory symptoms. ${ }^{10}$ In our study sex was taken into account and stratification by age, level of education, and father's occupation did not change the result. Although the non-response rate was $20 \%$, the responders reflected the Finnish population of the corresponding age by sex, place of residence, and province. Although the response rate was probably lower among smokers than non-smokers, a previous study did not show any bias in answering questions according to respiratory symptoms. ${ }^{10}$ No reason exists to believe that the groups of smokers were not comparable.

Our analysis implies that among young people smoking more than nine cigarettes daily the irritant effect of the new low tar cigarette (yielding less than $10 \mathrm{mg}$ tar) on the lung is significant and not, apparently, less than that of the medium tar cigarette (10-18 $\mathrm{mg}$ tar). The number of cigarettes smoked daily appears to be a much more important determinant of respiratory health than the brand's tar yield given by standard laboratory methods.

Recent studies have shown that the amounts of tar, nicotine,

TABLE III-Prevalences $(\%)$ of respiratory symptoms during last few days preceding study and $95 \%$ confidence intervals (CI) by sex and type and number of cigarettes smoked

\begin{tabular}{|c|c|c|c|c|c|c|c|c|c|c|}
\hline \multirow{3}{*}{ Symptom } & \multicolumn{5}{|c|}{ Boys } & \multicolumn{5}{|c|}{ Girls } \\
\hline & \multirow{2}{*}{ Never smoked } & \multicolumn{2}{|c|}{ 1-9 cigarettes daily } & \multicolumn{2}{|c|}{$9+$ cigarettes daily } & \multirow{2}{*}{ Never smoked } & \multicolumn{2}{|c|}{ 1-9 cigarettes daily } & \multicolumn{2}{|c|}{$9+$ cigarettes daily } \\
\hline & & Low tar & Medium tar & Low tar & Medium tar & & Low tar & Medium tar & Low tar & Medium tar \\
\hline $\begin{array}{l}\text { Morning phlegm: } \\
\text { Prevalence } \\
95^{\circ}, \mathrm{CI} \\
\text { n }\end{array}$ & $\begin{array}{l}2 \cdot 6 \\
1 \cdot 6-3 \cdot 6 \\
884\end{array}$ & $\begin{array}{l}2 \cdot 3 \\
0-6 \cdot 8 \\
43\end{array}$ & $\begin{array}{l}3 \cdot 8 \\
0-8 \cdot 0 \\
79\end{array}$ & $\begin{array}{l}11 \cdot 1 \\
3 \cdot 8-18 \cdot 4 \\
72\end{array}$ & $\begin{array}{l}11 \cdot 1 \\
6 \cdot 6-15 \cdot 6 \\
189\end{array}$ & $\begin{array}{l}2 \cdot 9 \\
1 \cdot 9-3 \cdot 9\end{array}$ & $\begin{array}{l}3 \cdot 5 \\
0 \cdot 5-6 \cdot 5 \\
143\end{array}$ & $\begin{array}{l}9 \cdot 9 \\
3 \cdot 4-16 \cdot 4 \\
81\end{array}$ & $\begin{array}{l}12 \cdot 2 \\
6 \cdot 2-18 \cdot 2 \\
115\end{array}$ & $\begin{array}{l}17 \cdot 4 \\
9 \cdot 4-25 \cdot 4 \\
86\end{array}$ \\
\hline $\begin{array}{l}\text { Morning cough: } \\
\text { Prevalence } \\
95^{\circ}{ }^{\circ} \mathrm{CI} \\
\mathrm{n}\end{array}$ & $\begin{array}{c}6 \cdot 1 \\
4 \cdot 5-7 \cdot 7 \\
884\end{array}$ & $\begin{array}{l}7 \cdot 0 \\
0-14 \cdot 6 \\
43\end{array}$ & $\begin{array}{l}7 \cdot 6 \\
1 \cdot 8-13 \cdot 4 \\
79\end{array}$ & $\begin{array}{l}23 \cdot 6 \\
13 \cdot 8-33 \cdot 4 \\
72\end{array}$ & $\begin{array}{l}20 \cdot 1 \\
14 \cdot 4-25 \cdot 8 \\
189\end{array}$ & $\begin{array}{c}6 \cdot 5 \\
5 \cdot 0-7 \cdot 9 \\
1147^{5}\end{array}$ & $\begin{array}{l}11 \cdot 2 \\
6 \cdot 0-16 \cdot 4 \\
143\end{array}$ & $\begin{array}{l}16 \cdot 0 \\
8 \cdot 0-24 \cdot 0 \\
81\end{array}$ & $\begin{array}{l}40 \cdot 0 \\
31 \cdot 0-49 \cdot 0 \\
115\end{array}$ & $\begin{array}{l}32 \cdot 6 \\
22 \cdot 7-42 \cdot 5 \\
86\end{array}$ \\
\hline $\begin{array}{l}\text { Phlegm day or nigl } \\
\text { Prevalence } \\
95{ }^{\circ} \text { CI } \\
n\end{array}$ & $\begin{array}{c}5 \cdot 2 \\
3 \cdot 7-6 \cdot 7 \\
869\end{array}$ & $\begin{array}{l}7 \cdot 0 \\
0-14 \cdot 6 \\
43\end{array}$ & $\begin{array}{l}10 \cdot 3 \\
3 \cdot 6-17 \cdot 0 \\
78\end{array}$ & $\begin{array}{l}15 \cdot 5 \\
7 \cdot 1-23 \cdot 9 \\
71\end{array}$ & $\begin{array}{l}11 \cdot 7 \\
7 \cdot 1-16 \cdot 3 \\
188\end{array}$ & $\begin{array}{c}5 \cdot 3 \\
4132^{4 \cdot 0-6 \cdot 6}\end{array}$ & $\begin{array}{l}12 \cdot 1 \\
6 \cdot 7-17 \cdot 5 \\
141\end{array}$ & $\begin{array}{l}10 \cdot 0 \\
3 \cdot 4-16 \cdot 6 \\
80^{-6}\end{array}$ & $\begin{array}{l}19 \cdot 1 \\
11 \cdot 9-26 \cdot 3 \\
115\end{array}$ & $\begin{array}{l}19 \cdot 8 \\
11 \cdot 4-28 \cdot 2 \\
86\end{array}$ \\
\hline $\begin{array}{l}\text { Cough day or nigh } \\
\text { Prevalence } \\
95^{\circ}{ }_{0} \mathrm{CI} \\
\mathrm{n}\end{array}$ & $\begin{array}{l}17 \cdot 3 \\
14 \cdot 8-19 \cdot 8 \\
869\end{array}$ & $\begin{array}{l}23 \cdot 3 \\
10 \cdot 7-35 \cdot 9 \\
43\end{array}$ & $\begin{array}{l}32 \cdot 1 \\
21 \cdot 7-42 \cdot 5 \\
78\end{array}$ & $\begin{array}{l}42 \cdot 3 \\
30 \cdot 8-53 \cdot 8 \\
71\end{array}$ & $\begin{array}{l}37 \cdot 8 \\
30 \cdot 9-44 \cdot 7 \\
188\end{array}$ & $\begin{aligned} & 20 \cdot 9 \\
& 18 \cdot 5-23 \cdot 2 \\
& 1132\end{aligned}$ & $\begin{array}{l}44 \cdot 0 \\
35 \cdot 8-52 \cdot 2 \\
141\end{array}$ & $\begin{array}{l}38 \cdot 8 \\
28 \cdot 1-49 \cdot 5 \\
80\end{array}$ & $\begin{array}{l}63 \cdot 5 \\
54 \cdot 7-72 \cdot 3 \\
115\end{array}$ & $\begin{array}{l}51 \cdot 2 \\
45 \cdot 9-56 \cdot 5 \\
86\end{array}$ \\
\hline
\end{tabular}


and carbon monoxide inhaled by people smoking low tar cigarettes can be higher than the yields measured by standard laboratory methods ${ }^{13-15}$ as machines do not smoke cigarettes in the same manner as people. ${ }^{13}$ Hence the real exposure to tar of the smokers of low tar cigarettes in this study may have been close to that of the smokers of medium tar cigarettes, which may account for the similar prevalence of symptoms between these two groups.

The decline in the yield of tar in cigarettes has contributed to the reduced risk of cancer of the lung and chronic obstructive pulmonary disease among smokers until recent years. ${ }^{16}$ Unfortunately, we have to wait for many years before the effects on health of new low tar brands of cigarettes can be shown in epidemiological studies using these diseases as an outcome. Many important differences in physical properties of new low tar cigarettes exist compared with the older ones, and therefore the conclusion referred to above cannot be interpreted as evidence that health hazards will diminish as a function of a yield of tar below $10 \mathrm{mg}$. On the contrary, our data and some other recent epidemiological ${ }^{7-9}$ and experimental ${ }^{17}$ studies have not shown any significant differences in the effects on health of low tar brands compared with the medium tar brands. Although we cannot draw conclusions on the risk of cancer of the lung or obstructive pulmonary diseases on the basis of these studies, the medical evidence available does not support the hypothesis that cigarettes yielding less than $10 \mathrm{mg}$ tar are safer than those yielding $10-18 \mathrm{mg}$.

The National Board of Health (Finland) and the Finnish Medical Research Council supported this study.

\section{References}

1 Hammond EC, Garfinkel L, Seidman H, Lew EA. Some recent findings concerning cigarette smoking. In: Hiatt $\mathrm{HH}$, Watson JD, Winsten JA, eds. Origins of human cancer. Book A. Hncidence of cancer in Laboratory, 1977:101-12.

2 Auerbach $\mathrm{O}$, Hammond EC, Garfinkel L. Changes in bronchial epithelium in relation to cigarette smoking, $1955-1960$ vs 1970-1977. N Engl J Med 1979; 300:381-6.

3 Higenbottam T, Clark TJH, Shipley MJ, Rose G. Lung function and symptom of cigarette smokers related to tar yield and number of cigarettes smoked.

4 US Department of Health and Human Services, Public Health Service. The health consequences of smoking. The changing cigarette. A report of the surgeon

Lee $\mathrm{P}$, Garfinkel $L$ Mortality and type of cigarette smoked. 7 Epidemiol Community Health 1981:35:16-22.

6 Schenker $M$, Samet J, Speizer $F$. Effect of cigarette tar content and smoking habits on respiratory symptoms in women. Am Rev Respir Dis 1982;125: habits

7 Petitti D, Friedman G, Kahn W. Peptic ulcer disease and the tar and nicotine yield of currently smoked cigarettes. F Chronic Dis 1982;35:503-7. aufman $\mathrm{D}$, Helmrich $S$, Rosenberg $\mathrm{L}$, Miettinen $\mathrm{O}$, Shapiro $\mathrm{S}$. Nicotine and carbon monoxide content of cigarette smoke and the risk of myocardial in farction in young men. N Engl 3 Med 1983;308:409-13.

9 Sparrow D, Stefos T, Bosse R, Weiss S. The relationship of tar content to decline in pulmonary function in cigarette smokers. Am Rev Respir Dis 1983 127:56-8.

10 Rimpelä A. Occurrence of respiratory diseases and symptoms among Finnish youth. A follow-up survey. Acta Paediatr Scand 1982;297(suppl):1-77. spective studies of disease. Journal of the National Cancer Institute 1959 . spective

12 Armitage P. Statistical methods in medical research. Oxford: Blackwell Scientific Publications, 1971 .

13 Kozlowski L, Rickert W, Pope M, Robinson JC, Frecker R. Estimating the yield to smokers of tar, nicotine, and carbon monoxide from the "lowest yield" ventilated filter-cigarettes. Br F Addict 1982;77:159-65.

14 Benowitz N, Hall S, Herning R, Jacob P, Jones R, Osman AL. Smokers of lowyield cigarettes do not consume less nicotine. N Engl $\mathcal{Y}$ Med 1983;309:139-42.

6 Peto R, Doll R. The control of lung cancer. New Scientist 1985;105:26-30.

Sorsa M, Falk K, Heinonen T, Vainio H, Norppa $H$, Rimpelä $M$. Detection of exposure to mutagenic compounds in low-tar and medium-tar cigarette smokers. Environ Res 1984;33:312-21.

\title{
Antibody guided irradiation of brain glioma by arterial infusion of radioactive monoclonal antibody against epidermal growth factor receptor and blood group $A$ antigen
}

\author{
A A EPENETOS, N COURTENAY-LUCK, D PICKERING, G HOOKER, H DURBIN, \\ J P LAVENDER, C G MCKENZIE
}

\begin{abstract}
In a patient with recurrent grade IV glioma of the brain resistant to conventional treatment an antibody guided isotopic scan showed uptake by the tumour of a monoclonal antibody (9A) that was developed against epidermal growth factor receptor but cross reacted with
\end{abstract}

Royal Postgraduate Medical School, Hammersmith Hospital, London W12 OHS

A A EPENETOS, PHD, MRCP, senior lecturer, department of radiotherapy and oncology

N COURTENAY-LUCK, BSC, DIBIOL, research assistant, department of radiotherapy and oncology

D PICKERING, MB, MRCP, senior registrar, department of radiotherapy and oncology

G HOOKER, BSC, physicist, department of medical physics

I P LAVENDER, MD, FRCR, professor of radiological sciences

C G MCKENZIE, FRCS, FRCR, consultant, department of radiotherapy and oncology

Imperial Cancer Research Fund, London WC2A 3PX H DURBIN, technician

Correspondence to: Dr A A Epenetos. blood group $A$ antigen. As a therapeutic attempt antibody labelled with $1665 \mathrm{MBq}(45.0 \mathrm{mCi})$ iodine-131 was delivered to the tumour area by infusion into the internal carotid artery. Computed tomography showed regression of the tumour after treatment, and an appreciable and sustained clinical improvement was noted without any toxicity.

Delivery of irradiation guided by monoclonal antibody delivered by arterial infusion of the tumour area may be of clinical value in the treatment of brain gliomas resistant to conventional forms of treatment.

\section{Introduction}

Grade IV glioma is one of the most rapidly fatal neoplasms, with a median survival of 14 weeks after biopsy. ${ }^{1}$ Postoperative radiotherapy extends survival and improves quality of life in most cases. ${ }^{2}$ The remission, however, is usually short lived and the long term survival rate negligible. Some evidence exists that the length of survival can be increased by giving higher doses of radiation. Salazar et al reported a small series of cases in which doses of $7500 \mathrm{cGy}$ ( $7.5 \mathrm{rads}$ ) were given to the tumour with apparent improvement in survival. ${ }^{3}$ High biological doses 